\title{
Sources of proteins in human bile
}

\author{
BARBARA M MULLOCK, LYNNE J SHAW, B FITZHARRIS, JANE PEPPARD, \\ M J R HAMILTON, M T SIMPSON, T M HUNT, AND R H HINTON
}

From Robens Institute of Industrial and Environmental Health and Safety, University of Surrey, Guildford, Surrey, Section of Tumour Immunology, Institute of Cancer Research, Belmont, Sutton, Surrey, Department of Microbiology, Bristol Royal Infirmary, Bristol, Westminster Hospital, Dean Ryle Street, London, and St Luke's Hospital, Guildford, Surrey

SUMmARY The proteins of 46 human bile specimens, collected by several different routes have been studied by crossed immunoelectrophoresis, by rocket immunoelectrophoresis and by radioimmunoassay. The results were analysed by plotting the variation in the bile:plasma ratio of particular proteins against molecular weight and by examination of the correlation between the concentrations of different proteins in the biles of different patients. Our results show that the majority of human bile proteins derive from plasma although bile specific proteins are always present. The majority of plasma proteins appear to enter bile by a 'sieving' mechanism which results in an inverse relationship between the bile:plasma ratio and the molecular weight. In addition there was a very high degree of correlation between the biliary concentrations of $\alpha_{2}-$ macroglobulin, IgG, haptoglobin, haemopexin, albumin, prealbumin, and orosomucoid. A number of other proteins namely thyroxine binding globulin, GC globulin and $\alpha_{2} \mathrm{HS}$ glycoprotein appeared in bile at concentrations greater than those expected if entry is by the sieving mechanism. These three proteins, however, are of rather low molecular weight and the reason for the lack of correlation appears to be individual variation in the 'pore size', presumably reflecting variation in the porosity of tight junction between hepatocytes. Although the majority of human bile proteins would appear to enter bile by a molecular weight-dependent pathway, four proteins, namely secretory $\operatorname{IgA}$, IgM, haemoglobin and caeruloplasmin, showed significant deviation from the predicted relationship and probably enter bile at least partly by transport across cells. The concentration of $\beta_{2}$-glycoprotein I was also much greater than expected from its molecular weight. The reason for this is not yet clear but may well reflect a very efficient and specific transport mechanism.

The principal proteins of rat bile, ${ }^{1}$ are, with the exception of secretory component, derived from plasma. ${ }^{2-4}$ Transfer from plasma to bile occurs both by transport across hepatocytes and by sieving across tight junctions (paracellular transport ${ }^{5}$ ), the former being quantitatively more important. In addition minor amounts of biliary protein are dissolved from the bile-facing cell surfaces or are derived from lysosomal discharge. These results are consistent with previous data published by Dive and colleagues ${ }^{6}$ on the composition of dog bile. Examination of other species such as chickens, ${ }^{4}$ pigs, ${ }^{4}$ sheep ${ }^{4}$ and guinea pigs $^{48}$ does, however, show

Address for correspondence: Dr B Mullock, Toxicology Unit, The Robens Institute, University of Surrey, Guildford, Surrey GU2 5XH.

Received for publication 13 July 1984 that there can be marked species variation in the importance of the transcellular pathway. In the species mentioned, the bulk of biliary protein probably derives from the paracellular pathway, whereas in dogs, cats and rabbits, ${ }^{4}$ as in rats, the bulk of the protein derives from transport across cells. The data of Dive and Heremans ${ }^{9}$ suggest that in human bile the bulk of protein probably reaches bile by the paracellular pathway. Since that time, however, many workers have found that human bile is rich in secretory $\operatorname{Ig} \mathrm{A}^{10-14}$ and that secretory $\operatorname{IgA}{ }^{14-18}$ and free secretory component ${ }^{18}{ }^{19}$ accumulate in serum in liver disease.

In rats, and other species, polymeric $\operatorname{IgA}$ is quantitatively the most important protein transferred from plasma to bile by passage across hepa- 
tocytes. ${ }^{4}$ It would appear that similar transport must occur in man although the precise site and quantity of transfer has been the subject of considerable debate. ${ }^{49} 9^{20-23}$ In rats, moreover, it seems clear that $\operatorname{IgA}$ is not the only protein which can be transferred from plasma to bile by passage across hepatocytes; this would also appear to be the route of transfer for haemoglobin, which appears in bile as a haptoglobin-haemoglobin complex ${ }^{24}$ and possibly for other proteins. ${ }^{25}$ The main systematic studies on human bile proteins are those carried out by Dive and Heremans in $1974^{9}$ in which only five proteins were investigated and the study of Delacroix et $a l^{26}$ which concentrated on biliary immunoglobulins. We have, accordingly, reinvestigated the protein composition of human bile using specimens drawn by a variety of techniques and using techniques which enable us to study a wide variety of different proteins.

\section{Methods}

MATERIALS

Monospecific antisera against human serum proteins were, when available, those prepared by Dako Immunoglobulins, (Copenhagen, Denmark) and supplied through Mercia Brocades (Byfleet, Surrey). Other antisera were purchased from Nordic Immunological Laboratories (Maidenhead, Berks), Seward Laboratories (London SE1) or Behringwerke AG (Marburg, West Germany). Anti-human bile antiserum was prepared in rabbits maintained in the University of Surrey animal house using the injection schedule described in earlier studies. ${ }^{27}$ Only 'normal' biles, as classified in paragraph 2 of the results section, were used in the antigen-mixtures injected.

Twelve bile samples from six patients, five of whom had undergone cholecystectomy were obtained by endoscopic retrograde choledochopancreatography (ERCP) and given to us by $\mathrm{Dr}$ Mary Chapple, Middlesex Hospital.

Six bile samples were obtained by T-tube drainage after cholecystectomy and provided by Dr Parveen Kumar, St Bartholomews Hospital and one sample from St Georges Hospital.

Thirteen samples were obtained by needle aspiration from the biliary tract at laparotomy from patients not known to have hepatobiliary disease, and were given to us by Mr Tim Cooke, Southampton General Hospital.

Bile from subjects without hepatobiliary disease was obtained by aspiration from the duodenum. One sample was a pool of duodenal juice from 12 normal volunteers and the gift of $\mathrm{Dr} J o h n$ Thornton, Bristol Royal Infirmary, and two were from patients being investigated at Addenbrookes Hospital, Cambridge and were provided by $\mathrm{Dr}$ Mary Calladine.

Fourteen matched serum and bile samples from 13 patients were obtained from patients undergoing T-tube drainage at St Lukes Hospital, Guildford after either cholecystectomy or after biliary obstruction resulting from carcinoma of the head of the pancreas. Five matched bile and serum samples from four patients were also obtained at Westminster Hospital by aspiration of gall bladder contents within five minutes of surgical removal.

When more than one sample was obtained from a single patient, only one specimen was used in the main analysis. A selected series of test were carried out on the remaining specimen to determine whether there were significant alterations with time of collection.

Bile proteins were analysed by crossed immunoelectrophoresis according to Axelsen et al. ${ }^{28}$ Quantitation of proteins in serum and bile was carried out by rocket immunoelectrophoresis. ${ }^{28}$ In all cases a range of dilutions of, as appropriate, normal human serum or the matched patient serum was run on the same plate. Results from bile samples were only accepted if they lay within the range of serum standards. Haptoglobin:haemoglobin complexes were estimated by rocket immunoelectrophoresis against anti-human haemoglobin. This procedure is valid, because results presented below show no free haemoglobin in any serum or bile specimen.

Secretory IgA was assayed by an adaptation ${ }^{14}$ of the radioimmunoassay procedure of Peppard. ${ }^{29}$ The antiserum was an anti-(human secretory component) made by methods similar to those of Socken and Underdown. ${ }^{30}$ Briefly, human secretory component was prepared by passing spun human milk through a column containing human polymeric $\operatorname{IgA}$ immobilised by binding to cyanogen bromide activated Sepharose. Bound secretory component was eluted with $1.5 \mathrm{M}$ potassium thiocyanate at $4^{\circ} \mathrm{C}$. Antiserum to this preparation, raised in rabbits, was purified by absorption with monomeric $\operatorname{IgA}$, lactoferrin and normal human serum. The resulting antiserum was specific for secretory $\operatorname{IgA}$ and free secretory component. Free secretory component, measured by crossed immunoelectrophoresis with a split antibody containing gel, ${ }^{28}$ however, was detected in only a minority of bile samples and never amounted to more than $15 \%$ of the material reacting with the antiserum. ${ }^{4}$ The secretory IgA used as a standard was a mixture of dimeric and trimeric secretory IgA prepared from human milk by a combination of ion exchange chromatography and gel filtration on 
Ultrogel AcA22 and AcA34 (LKB Instruments, Croyden, Surrey).

Statistical analysis of the results was carried out using the 'correlation' and 'regression' procedures of the MINITAB statistical package Release $82 \cdot 1$ (University of Pennsylvania Statistical Laboratory) implemented on the University of Surrey's Prime Computer.

\section{Results}

The means of collection of bile specimens and the provisional diagnosis of the patients are indicated in Table 1. Two dimensional agarose gradient polyacrylamide gel electrophoresis of human biles showed a protein pattern similar to that of human serum although with a notable depletion of high molecular weight proteins (not illustrated). In particular bile specimens from persons bearing the $\mathrm{Hp}_{2}{ }^{\alpha}$ haptoglobin gene showed a similar 'ladder' of bands caused by haptoglobin monomers as did serum specimens from such individuals. Crossed immunoelectrophoresis against antihuman serum and an antiserum raised against human bile showed that the majority of human bile proteins reacted with anti-human serum (Fig. 1) although some bile-specific proteins were consistently present.

Bile samples were collected from 46 different patients. Study of the concentrations of particular proteins in the initial batch of 29 samples showed that the bile specimens could be divided into three groups. In the majority of specimens, there was, for major plasma proteins such as $\mathrm{IgG}$, transferrin and albumin, a linear relationship between the ratio of the biliary and normal plasma concentration and the reciprocal of the molecular weight as has already been described by Dive and Heremans (Fig. 2a). Significant numbers of patients, however, had very large amounts of high molecular weight proteins in their bile (Fig. 2b). In these patients there was little change in the bile-plasma ratio with molecular weight, which is consistent with massive leakage of plasma into bile. These were classified as plasma-rich biles. There appeared to be a clear cut distinction between the two groups - whereas the range of $\alpha_{2}$ macroglobulin in the 23 normal biles was $0-1.9 \%$ of the plasma concentration, that in the five plasma-rich biles was $5 \cdot 0-6 \cdot 8 \%$ of the plasma concentration. Other patients had practically no proteins present in their biles (classified in Table 1 as protein-poor biles). There was no correlation between the amount of protein in the bile and either the means of collection or the provisional diagnosis (Table 1). No systematic differences could be observed between biles obtained by T-tube drainage and those obtained by what seemed to be the least invasive procedure, withdrawal during laparotomy. Very similar patterns were obtained when biles from the same patient were examined at different times after cholecystectomy with T-tube drainage or after endoscopic exploration of the bile duct.

Although the biliary concentrations of the majority of proteins which we examined obeyed the reciprocal relationships with molecular weight, as is clear from Fig. 2, six proteins, namely $\operatorname{IgA}$, caeruloplasmin, haptoglobin, haemoglobin, orosomucoid and $\beta_{2}$-glycoprotein I, were present in bile at concentrations significantly greater than would be predicted from the concentrations of proteins such as albumin. Of these proteins a considerable proportion of the $\operatorname{IgA}$ was combined with

Table 1 Source and nature of human bile samples examined in the current study. Normal, 'plasma rich' and 'protein poor' biles are defined in paragraph 2 of the results section. In summary plasma rich biles are those in which the concentration of $\alpha_{2}$-macroglobulin was greater than $1 \%$ of its serum value while 'protein poor' biles are those in which the concentration of albumin was less than $0.5 \%$ of its plasma value. 'Normal' biles showed a linear relationship between the concentration of major serum proteins and the reciprocal of the molecular weight. 'Other' biles showed anolomous features some of which could have been caused by proteolysis

\begin{tabular}{|c|c|c|c|c|c|c|c|}
\hline & \multirow{2}{*}{$\begin{array}{l}\text { Carcinoma of } \\
\text { pancreas }\end{array}$} & \multicolumn{2}{|c|}{ T tube drainage after* } & \multirow{2}{*}{$\begin{array}{l}\text { Endoscopic } \\
\text { drainage }\end{array}$} & \multirow{2}{*}{$\begin{array}{l}\text { Aspiration from } \\
\text { bile duct }\end{array}$} & \multirow{2}{*}{$\begin{array}{l}\text { Duodenal } \\
\text { aspiration }\end{array}$} & \multirow{2}{*}{$\begin{array}{l}\text { Gall bladder } \\
\text { content }\end{array}$} \\
\hline & & Cholangioma & Cholecystectomy & & & & \\
\hline Normal & 1 & 2 & 5 & 5 & 9 & 0 & 2 \\
\hline Plasma-rich & 2 & 0 & 1 & 1 & 4 & 0 & 1 \\
\hline Protein poor & 1 & 0 & 3 & 0 & 0 & 0 & 0 \\
\hline Other & 2 & 0 & 0 & 0 & 0 & 3 & 0 \\
\hline
\end{tabular}

${ }^{*}$ Four samples were supplied without summaries of clinical notes.

† These biles contained little protein other than secretory IgA. This could be explained by partial aspiration of gastric contents or, more likely, by partial proteolysis. 


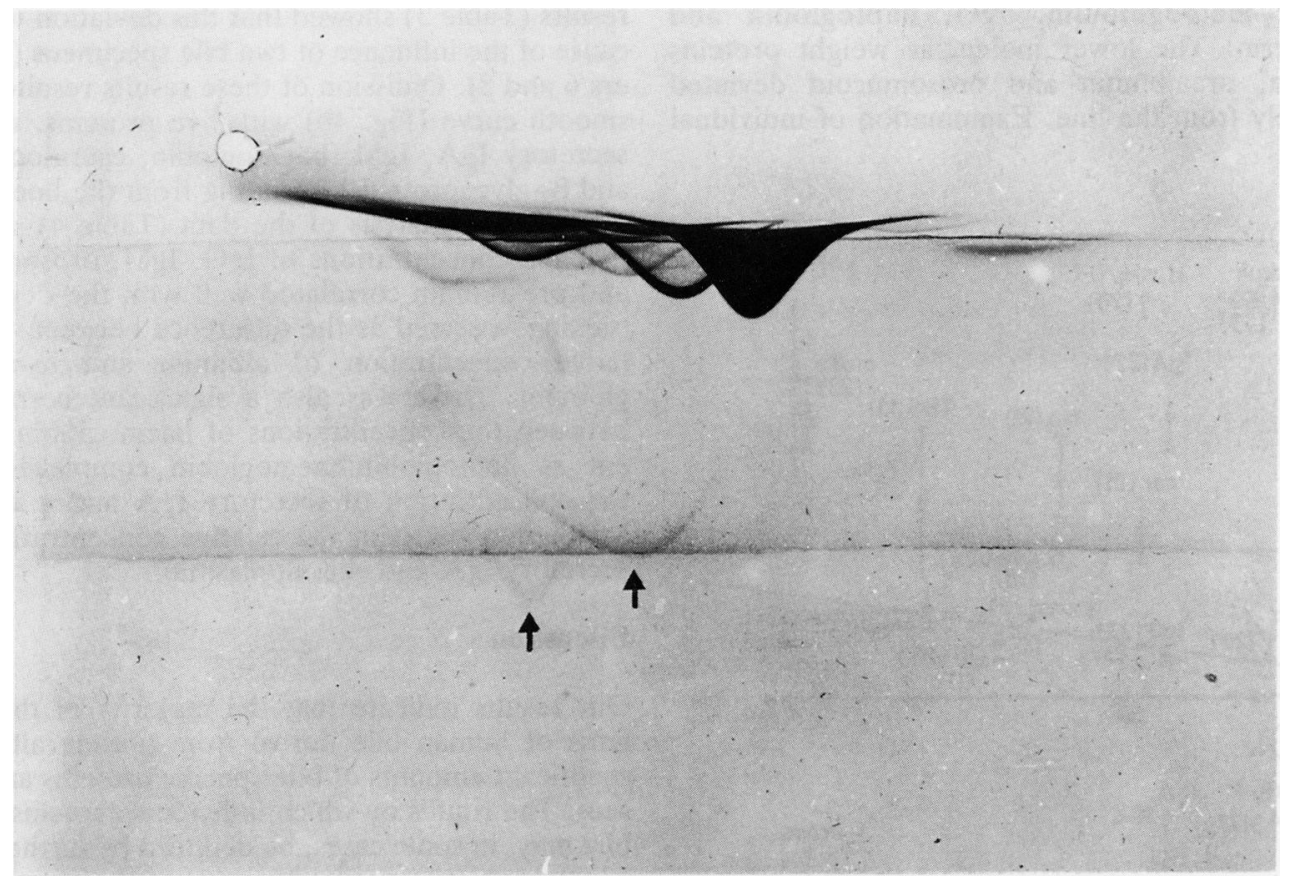

Fig. 1 Pattern obtained after crossed immuno-electrophoresis of $5 \mu$ l of a human bile specimen. Electrophoresis in the second dimension was against a split antibody-containing gel containing in the lower part 5\% anti-human serum (Dako, Copenhagen) and in the upper part $5 \%$ anti-human bile. It should be noted that, because of cathodic drift of IgG, the precipitation lines indicated by arrows which are due to proteins reacting with anti-(human bile) but not with anti-(human serum) appear somewhat below the junction of the two gels.

secretory component while haemoglobin was present in the form of haptoglobin:haemoglobin complexes (Fig. 3).

For the purposes of mathematical analysis, the biliary concentration relative to normal plasma of the high molecular weight protein $\alpha_{2}$-macroglobulin may be taken as an indication of the extent of direct leakage. The differences between the relative concentrations of albumin and $\alpha_{2}-$ macroglobulin may be taken as an indicator of the amount of protein transported by sieving. We accordingly carried out a statistical analysis of the variations of concentrations of proteins in different biles in relation to these parameters and to the concentration of secretory IgA. The results (Table 2) show that most of the variation in the concentrations of IgG, transferrin, haemopexin, prealbumin and orosomucoid correlate with variations in albumin and $\alpha_{2}$-macroglobulin concentrations whereas the variations in $\operatorname{IgA}$, haptoglobin, haemoglobin, caeruloplasmin, thyroxine-binding globulin and $\beta_{2}$-glycoprotein I show no such correlation, although neither do they correlate well with concentrations of secretory $\operatorname{IgA}$ in the bile. The plasma concentration of several of these proteins is known to change in disease, however, and we therefore felt that some of the variation in biliary concentrations could be because of variations in the concentrations in plasma. We accordingly carried out a second series of studies on patients where we were able to obtain plasma samples drawn at approximately the same time as the sample of bile.

When matched specimens were received, we initially measured the concentrations of $\alpha_{2}$-macroglobulin and albumin in plasma and bile. The two specimens in which $\alpha_{2}$-macroglobulin in bile was greater than $1 \%$ of the plasma concentration or those in which the albumin was either less than $0.5 \%$ of plasma concentration or similar to the $\alpha_{2}$ macroglobulin were rejected as 'abnormal'. Analysis of the relative concentration of proteins in bile and plasma (Fig. 4a) then showed a linear relationship between the relative biliary concentration of proteins and the reciprocal of the molecular weight for the higher molecular weight prot- 
eins $\alpha_{2}$-macroglobulin, IgG, haptoglobin and transferrin. The lower molecular weight proteins albumin, prealbumin and orosomucoid deviated markedly from the line. Examination of individual

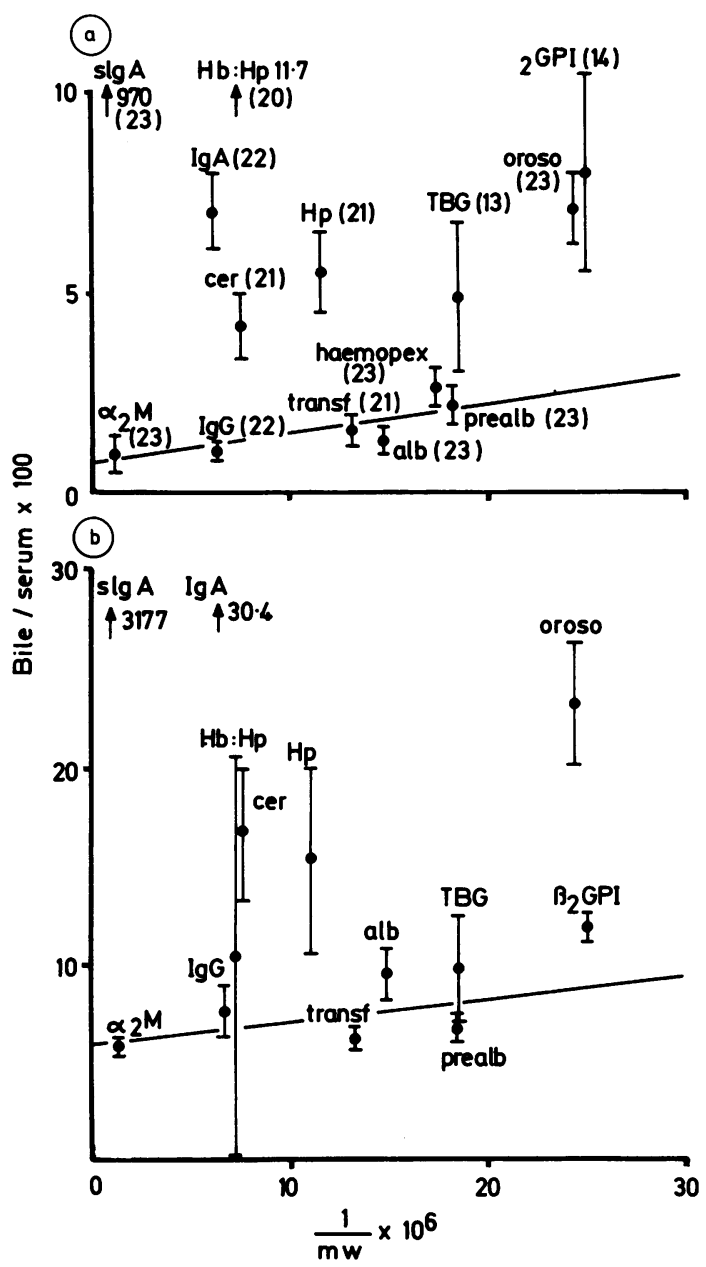

Fig. 2 Relationship between the concentration of proteins in bile, expressed as a ratio of the concentration of the same protein in normal human serum, to the inverse of the molecular weight of the protein. (a) Results from 23

'normal' bile specimens. (b) Results from 5 bile specimens containing large amounts of plasma proteins (plasma rich biles). The bars extend one standard error on each side of the mean. The number in brackets after the name of each protein shows the number of patients in which that protein was actually measured. Thyroxine-binding globulin could only be measured in biles relatively rich in plasma proteins. The results have accordingly been scaled down by the ratio of the relative albumin concentration in these biles to the relative albumin concentration in all bile specimens. results (Table 3 ) showed that this deviation was because of the influence of two bile specimens (numbers 6 and 8). Omission of these results resulted in a smooth curve (Fig. 4b) with five proteins, namely secretory $\operatorname{IgA}$, IgM, haemoglobin, caeruloplasmin and $\beta_{2}$-glycoprotein I deviating from the line.

Statistical analysis of the data (Table 4) showed that the concentrations of IgG, IgM, orosomucoid and prealbumin correlated well with the degree of 'sieving' assessed as the difference between the relative concentration of albumin and $\alpha_{2}$-macroglobulin. There was also a significant correlation between the concentrations of haemoglobin (present as haptoglobin:haemoglobin complexes) and the concentration of secretory IgA and a weaker correlation between the relative concentrations of secretory $\operatorname{IgA}$ and caeruloplasmin.

\section{Discussion}

Our results indicate that the majority of the proteins of human bile derive from plasma although significant amounts of bile-specific proteins are present. The routes by which individual proteins reach bile may, in some cases, be deduced by further con-

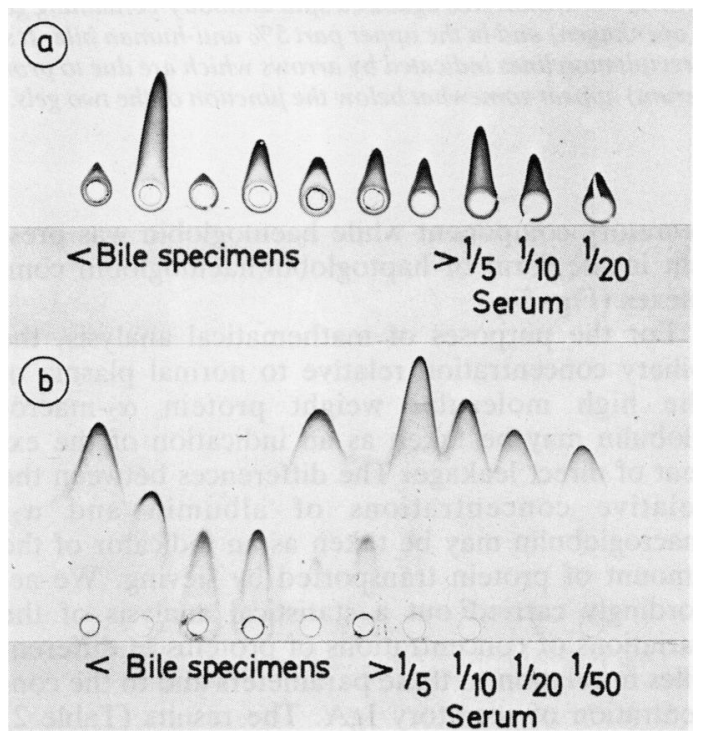

Fig. 3 Rocket immunoelectrophoresis of human bile specimens and dilutions of a 'normal' human serum against: (a) A split antibody-containing gel with, in the lower part, $2 \%$ anti-human haptoglobin and, in the upper part $1.5 \%$ anti-human haemoglobin. (b) A split antibody-containing gel with, in the lower part, $1.5 \%$ anti-human haemoglobin and, in the upper part, $2 \%$ anti-human haptoglobin. 
Table 2 Correlation between amounts of proteins in individual biles relative to the concentrations in normal human plasma and the relative concentration of (1) $\alpha_{2}$-macroglobulin $\left[\alpha_{2} M\right]^{r}$, taken as a measure of the leakage of whole plasma into bile, (2) the difference between the relative concentrations of albumin $[A l b]^{r}$ and $\alpha_{2}-$ macroglobulin, taken as a measure of sieving of proteins across tight junctions and (3) the relative concentration of secretory $\operatorname{Ig} A[s \operatorname{IgA}]^{r}$. The regression equation fitted was:

$[X]^{r}=a+b\left[\alpha_{2} M\right]^{r}+c\left([A l b]^{r}-\left[\alpha_{2} M\right]^{r}\right)+d[s I g A]^{r}$

where $[X]^{r}$ is the concentration of the protein under study. The results presented below show the calculation regression coefficients $a, b, c$ and $d$ and the \% of the variation of $[X]^{r}$ explained by the three regressors, entered in the order given and the unexplained variation.

\begin{tabular}{|c|c|c|c|c|c|c|c|c|c|}
\hline \multirow[b]{2}{*}{ Protein } & \multirow[b]{2}{*}{ No } & \multirow[b]{2}{*}{$a$} & \multirow[b]{2}{*}{$b$} & \multirow[b]{2}{*}{$c$} & \multirow[b]{2}{*}{$d$} & \multicolumn{3}{|c|}{$\%$ of sum of squares explained by } & \multirow{2}{*}{$\begin{array}{l}\text { Unexplained } \\
\text { variation } \%\end{array}$} \\
\hline & & & & & & {$\left[\alpha_{2} M\right]^{r}$} & {$[A l b]^{r}-\left[\alpha_{2} M\right]^{r}$} & $\lfloor s \operatorname{Ig} A\rceil^{r}$ & \\
\hline IgG & 26 & 0.057 & $0.916^{*}$ & $1 \cdot 09^{*}$ & -0.0003 & $58 \cdot 6$ & 35 & 0.5 & $5 \cdot 9$ \\
\hline Orosomucoid & 27 & $4 \cdot 33^{*}$ & $2 \cdot 38^{*}$ & $1.75^{*}$ & $0 \cdot 0005$ & $59 \cdot 2$ & $14 \cdot 3$ & $0 \cdot 2$ & $26 \cdot 3$ \\
\hline Prealbumin & 27 & $0.75^{*}$ & $0 \cdot 81^{*}$ & 0.23 & 0.0004 & $77 \cdot 8$ & $5 \cdot 7$ & $1 \cdot \overline{5}$ & $15 \cdot 0$ \\
\hline Transferrin & 25 & 0.337 & $0.49^{*}$ & 0.126 & $0 \cdot 0008^{*}$ & $72 \cdot 0$ & $5 \cdot 6$ & $2 \cdot 3$ & $16 \cdot 5$ \\
\hline Haemopexin & 26 & $1 \cdot 27$ & $0.99^{*}$ & 0.87 & -0.0001 & $44 \cdot 4$ & $12 \cdot 3$ & 0 & $43 \cdot 1$ \\
\hline IgA (total) & 25 & $4 \cdot 49^{*}$ & -0.007 & 0.593 & 0.0018 & 8.7 & $6 \cdot 2$ & $5 \cdot 8$ & $85 \cdot 1$ \\
\hline Haptoglobin & 24 & $8 \cdot 83$ & $-1 \cdot 10$ & $1.54^{\prime}$ & 0.003 & 0 & $12 \cdot 1$ & $2 \cdot 8$ & 85 \\
\hline Haemoglobin & 26 & $2 \cdot 4$ & $1 \cdot 19$ & $1 \cdot 56$ & 0.0027 & $36 \cdot 8$ & $11 \cdot 2$ & $2 \cdot 7$ & 55 \\
\hline Caeruloplasmin & 25 & $2 \cdot 94^{*}$ & $0 \cdot 71$ & $-0 \cdot 26$ & 0.0003 & $32 \cdot 6$ & 0.4 & 0.4 & $66 \cdot 5$ \\
\hline Thyroxine-binding globulin & 16 & $5 \cdot 28$ & 0.39 & 0.85 & 0.0009 & $0 \cdot 15$ & $2 \cdot 4$ & 15 & $95 \cdot 9$ \\
\hline$\beta_{2}$-Glycoprotein I & 17 & $7 \cdot 56$ & 0.46 & 0.58 & 0.0009 & 0 & $3 \cdot 3$ & $4 \cdot 1$ & $96 \cdot 3$ \\
\hline
\end{tabular}

An asterisk against any of the regression coefficients indicates it to be significantly different from zero, $(p<0 \cdot 05)$. No $=$ number of biles studied.

sideration of the data. In humans, as in rats, plasma proteins may be transferred to bile either by transport across hepatocytes or by the transcellular pathway. In addition a minority of the present bile specimens, although not visibly tainted with blood, appeared to show evidence of direct leakage of total plasma into bile for they contained a high concentration of plasma proteins and the concentration of particular proteins, relative to plasma, showed little dependence on molecular weight. It seems likely that such direct leakage occurs between damaged hepatocytes or bile duct lining cells for although the sinusoidal endothelium will prevent passage of red blood cells it provides no significant barrier to the passage of plasma proteins. Biles which appear to show such direct

Table 3 Concentration of proteins in 10 human specimens given as a percentage of the concentration of the same protein in plasma

\begin{tabular}{|c|c|c|c|c|c|c|c|c|c|c|}
\hline & \multicolumn{10}{|l|}{ Patient } \\
\hline & 1 & 2 & 3 & 4 & 5 & 6 & 7 & 8 & 9 & 10 \\
\hline Albumin & $0 \cdot 8$ & $1 \cdot 5$ & $1 \cdot 3$ & $1 \cdot 2$ & 2 & $19 \cdot 8$ & $1 \cdot 5$ & $19 \cdot 4$ & 1.9 & $1 \cdot 5$ \\
\hline$\alpha_{2}$-Macroglobulin & $0 \cdot 6$ & 0.4 & 0.5 & $0 \cdot 6$ & $0 \cdot 8$ & 0 & $1 \cdot 3$ & 0.8 & $0 \cdot 2$ & 0.5 \\
\hline IgG & $0 \cdot 7$ & 0.6 & $0 \cdot 6$ & $0 \cdot 6$ & $1 \cdot 7$ & $1 \cdot 7$ & $2 \cdot 1$ & $3 \cdot 4$ & $1 \cdot 0$ & $2 \cdot 3$ \\
\hline IgM & $7 \cdot 5$ & $2 \cdot 3$ & 1.9 & $8 \cdot 9$ & $9 \cdot 4$ & $13 \cdot 6$ & $2 \cdot 7$ & 58 & 0 & 20 \\
\hline Secretory IgA & 1176 & 110 & 170 & 799 & 167 & 371 & 1673 & 439 & 211 & 823 \\
\hline Orosomucoid & $1 \cdot 6$ & $2 \cdot 3$ & $1 \cdot 8$ & $4 \cdot 4$ & $4 \cdot 3$ & $23 \cdot 4$ & $9 \cdot 2$ & $14 \cdot 5$ & $3 \cdot 6$ & 2.9 \\
\hline Prealbumin & $7 \cdot 5$ & 1.9 & $2 \cdot 2$ & $1 \cdot 2$ & $4 \cdot 5$ & $31 \cdot 1$ & $9 \cdot 4$ & $31 \cdot 3$ & $4 \cdot 3$ & $5 \cdot 5$ \\
\hline Transferrin & $1 \cdot 0$ & $1 \cdot 0$ & $1 \cdot 1$ & $0 \cdot 3$ & $1 \cdot 6$ & $1 \cdot 0$ & $2 \cdot 1$ & 1.5 & 1.8 & $2 \cdot 3$ \\
\hline Haemopexin & $1 \cdot 8$ & $7 \cdot 4$ & $0 \cdot 7$ & $2 \cdot 1$ & $3 \cdot 8$ & 0 & 1.9 & 0 & $3 \cdot 6$ & $3 \cdot 3$ \\
\hline Haptoglobin & 0.4 & $0 \cdot 6$ & 0.5 & $0 \cdot 8$ & 1.4 & $0 \cdot 5$ & $7 \cdot 0$ & $0 \cdot 8$ & $0 \cdot 6$ & $1 \cdot 3$ \\
\hline Haemoglobin & $3 \cdot 1$ & $0 \cdot 8$ & $0 \cdot 3$ & $5 \cdot 7$ & 0 & 0 & $25 \cdot 2$ & 0 & 0 & $15 \cdot 8$ \\
\hline Caeruloplasmin & $1 \cdot 7$ & $1 \cdot 8$ & $1 \cdot 7$ & 0 & $1 \cdot 8$ & $2 \cdot 3$ & $6 \cdot 3$ & 0 & $1 \cdot 2$ & $4 \cdot 7$ \\
\hline$\alpha_{2}$ HS-Glycoprotein & $4 \cdot 2$ & $1 \cdot 2$ & 0.7 & $2 \cdot 2$ & $2 \cdot 8$ & 0 & $4 \cdot 5$ & 0 & $2 \cdot 9$ & $2 \cdot 5$ \\
\hline$\beta_{2}$-glycoprotein & $46 \cdot 4$ & 17 & $21 \cdot 4$ & ND & ND & 0 & $14 \cdot 7$ & ND & ND & ND \\
\hline GC-globulin & $8 \cdot 9$ & $3 \cdot 75$ & $2 \cdot 2$ & ND & ND & 0 & $14 \cdot 7$ & ND & ND & ND \\
\hline
\end{tabular}



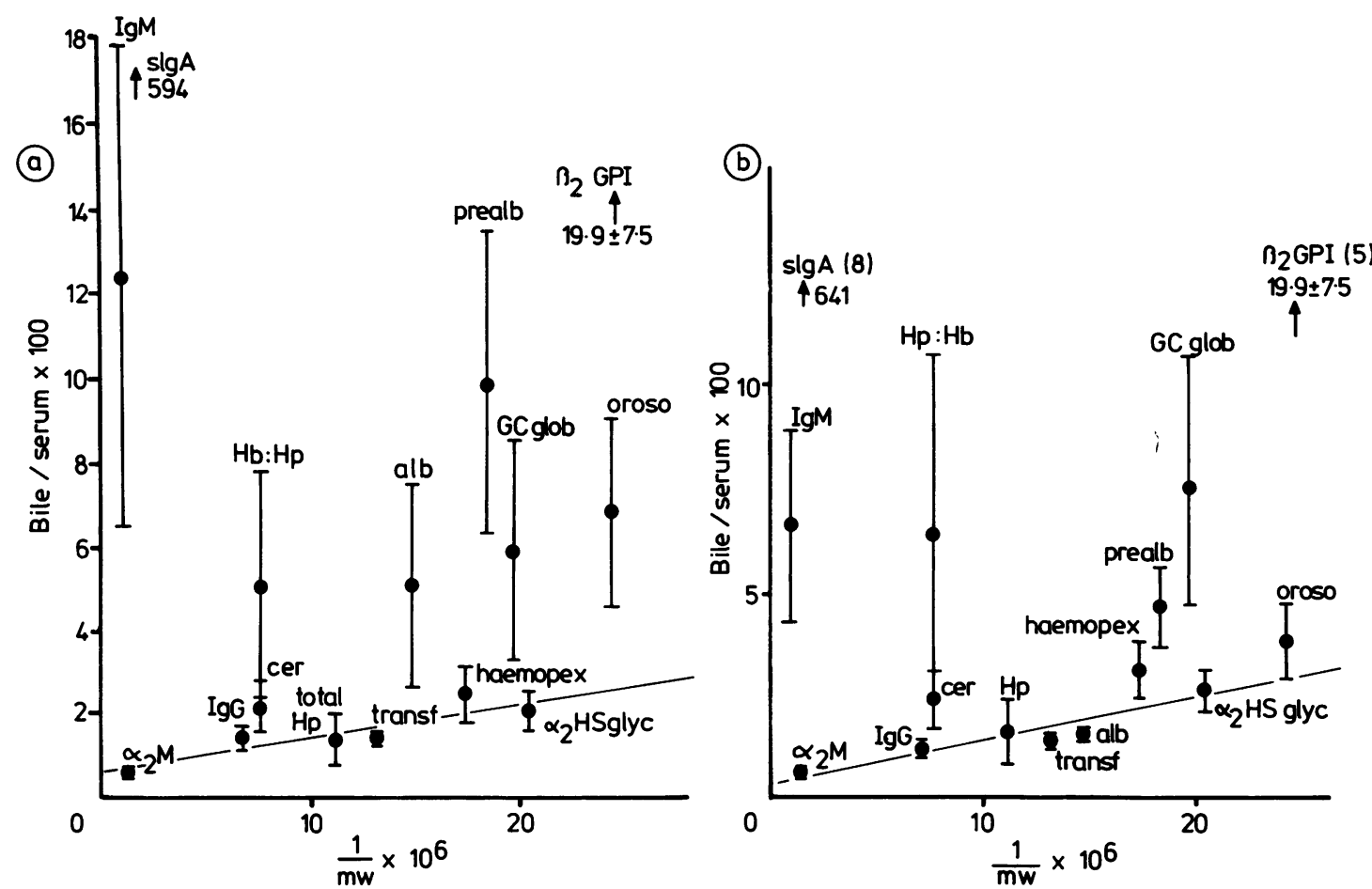

Fig. 4 Relationship between the concentration of proteins in bile, expressed as a ratio of the concentrations of the same protein in plasma of the same patient, to the inverse of the molecular weight of the protein: (a) Results from all 10 specimens examined. (b) Results omitting the two biles (Table 3, Nos 6 and 8) with anomalously high albumin concentrations.

Table 4 Correlation between amounts of proteins in 10 individual biles relative to the concentrations in plasma from the same patient and the relative concentration of (1) $\alpha_{2}$-macroglobulin $\left[\alpha_{2}-M\right]^{r}$, taken as a measure of the leakage of whole plasma into bile, (2) the difference between the relative concentrations of albumin $[A l b]^{r}$ and $\alpha_{2}$-macroglobulin, taken as a measure of sieving of proteins across tight junctions and (3) the relative concentration of secretory IgA [sIgA ${ }^{r}$. The regression equation fitted was:

$[X]^{r}=a+b\left[\alpha_{2} M\right]^{r}+c\left([A l b]^{r}-\left[\alpha_{2} M\right]^{r}\right)+d[\operatorname{sig} A]$

where $[X]^{r}$ is the concentration of the protein under study. The results presented below show the calculation regression coefficients $a, b, c$ and $d$ and the \% of the variation of $[X]^{r}$ explained by the three regressors, entered in the order given and the unexplained variation.

\begin{tabular}{|c|c|c|c|c|c|c|c|c|}
\hline \multirow[b]{2}{*}{ Protein } & \multirow[b]{2}{*}{$a$} & \multirow[b]{2}{*}{$b$} & \multirow[b]{2}{*}{$c$} & \multirow[b]{2}{*}{$d$} & \multicolumn{3}{|c|}{$\%$ of sum of squares explained by } & \multirow{2}{*}{$\begin{array}{l}\text { Unexplained } \\
\text { variation \% }\end{array}$} \\
\hline & & & & & {$\left[\alpha_{2} M\right]^{r}$} & {$[A l b]^{r}-\left[\alpha_{2} M\right]^{r}$} & {$[s I g A]^{r}$} & \\
\hline IgG & $0 \cdot 16$ & $1 \cdot 62$ & $0.09^{*}$ & 0 & $13 \cdot 3$ & $53 \cdot 3$ & 0 & $33 \cdot 4$ \\
\hline IgM & -5.94 & $24 \cdot 3$ & $1 \cdot 77^{*}$ & 0.0059 & $2 \cdot 3$ & $60 \cdot 0$ & 1.9 & $35 \cdot 8$ \\
\hline Orosomucoid & 1.43 & $-1 \cdot 19$ & $0.87^{*}$ & 0.0036 & $3 \cdot 4$ & $80 \cdot 1$ & $4 \cdot 1$ & $12 \cdot 4$ \\
\hline Prealbumin & $-0 \cdot 66$ & $2 \cdot 12$ & $1 \cdot 53$ & $0 \cdot 0041^{*}$ & $1 \cdot 7$ & $94 \cdot 7$ & $2 \cdot 0$ & 1.53 \\
\hline Transferrin & 1.04 & 0.52 & 0 & 0 & $10 \cdot 9$ & 0 & 0.2 & 88.9 \\
\hline Haemopexin & $4 \cdot 39$ & $-0 \cdot 12$ & $-0 \cdot 19$ & -0.0017 & 0.5 & $37 \cdot 0$ & $9 \cdot 5$ & $53 \cdot 1$ \\
\hline Haptoglobin & $3 \cdot 32-1 \cdot 25$ & 3.00 & 0.01 & 0.0015 & 58.9 & 0 & $9 \cdot 1$ & $32 \cdot 0$ \\
\hline Haemoglobin & $-3 \cdot 32$ & 3.69 & $-0 \cdot 14$ & $0.0046^{*}$ & 39.7 & $2 \cdot 4$ & $29 \cdot 7$ & $28 \cdot 2$ \\
\hline Caeruloplasmin & $1 \cdot 0$ & 0.06 & 0.03 & 0.0021 & $16 \cdot 6$ & $2 \cdot 6$ & $19 \cdot 2$ & $61 \cdot 6$ \\
\hline$\alpha_{2}$ HS-glycoprotein & $1 \cdot 65^{*}$ & $-0 \cdot 07$ & $-0 \cdot 12$ & 0.0017 & $26 \cdot 1$ & $33 \cdot 8$ & $19 \cdot 0$ & $21 \cdot 0$ \\
\hline
\end{tabular}

An asterisk against any of the regression coefficients indicates it to be significantly different from zero, $(\mathrm{p}<0 \cdot 05)$. 
leakage have been excluded from the further analysis of results as have the minority which contained very little protein of any kind as in both cases it seemed likely that surgical procedures and/or the underlying clinical condition which necessitated them had seriously affected the composition of the bile. The remaining samples, while clearly not a random sample of a normal healthy population show a consistent pattern which allows analysis of the mechanisms which govern the protein composition of human bile. The pattern obtained is not the result of the influence of the underlying liver disease for samples obtained by aspiration from the bile duct after laparotomy for conditions not connected with liver disease showed a similar pattern to 'normal' bile obtained, for example, from drainage after cholecystectomy.

In the majority of bile specimens, however, the concentrations of major plasma proteins were markedly dependent on molecular weight. The pioneering studies of Heremans and his colleagues ${ }^{6} 9$ showed that both in man and in dogs the variation in concentration in bile of the major plasma proteins albumin, orosomucoid, $\alpha_{2}$-macroglobulin and IgG could be explained by sieving through 'pores' with a maximum effective radius of $12.7 \mathrm{~nm}$ in man and $11.3 \mathrm{~nm}$ in dogs. Our studies show that, in addition to the four proteins mentioned, the bulk of bile haptoglobin, transferrin and prealbumin reach bile by sieving. For these proteins, the ratio of biliary to plasma concentrations plotted against the reciprocal of the molecular weight for each protein gives a straight line. Moreover, their biliary concentrations correlate well with the concentrations of albumin and $\alpha_{2}$-macroglobulin in the same bile. The situation is less clear cut for a few other proteins, namely haemopexin, thyroxinebinding globulin, GC globulin and $\alpha_{2}$ HSglycoprotein. The mean concentration of these proteins in bile, relative to their concentrations in serum are approximately those expected from their molecular weights (shown in Figs. 2 and 4 ) but the bile/serum ratios in individual patients (presented in Tables 2 and 4) correlate badly with the bile/ serum ratios of albumin and $\alpha_{2}$-macroglobulin. All these proteins are, however, lower in molecular weight than albumin and the variation could be explained if there is individual variation in the degree of sieving of low molecular weight protein. Plotting the serum/bile ratios presented in Table 3 in individual patients against the inverse of molecular weight suggested that this is indeed the case. These results suggest that in some individuals the permeability of the barrier between blood and bile increases sharply at molecular weights of less than 60000 . In the majority of patients upturn in the curve is found at lower molecular weights, indicating that the permeability change normally occurs at a molecular weight of around or below 40000 . This suggests that the permeability of the blood-bile barrier is similar to that of the bloodurine barrier, ${ }^{31}$ which is likely because the permeability of tight junctions between hepatocytes probably governs the entry of proteins into bile in the same way as the permeability of tight junctions between podocytes governs entry of proteins into urine. ${ }^{32}$

Thus the majority of bile proteins seem to derive from ultrafiltration of blood through the tight junctions between hepatocytes, the so called paracellular pathway. ${ }^{5}$ There are, however, several notable exceptions namely, haptoglobin:haemoglobin complexes, $\beta_{2}$ glycoprotein 1 and possibly caeruloplasmin. There is considerable evidence (see introduction) that secretory $\operatorname{IgA}$ is transferred into human bile by transport across cells although there is dispute as to whether transfer occurs across bile duct lining cells or hepatocytes. The low correlation between the bile:plasma ratios of total $\operatorname{IgA}$ and the bile:plasma or total (results not presented) levels of $\operatorname{sIg} \mathrm{A}$ found in this study does, however, indicate that appreciable amounts of $\operatorname{IgA}$ enter bile independently of secretory component. This is consistent with the report ${ }^{26}$ of significant amounts of monomeric $\operatorname{IgA}$ in humen bile. In the present study we found that the concentration of haptoglobin: haemoglobin complexes was much greater in bile than would be expected from the molecular weight of these complexes. This is unlikely to be caused by bleeding into the biliary tree as the effect is most marked in bile in which there are minimal amounts of high molecular weight plasma proteins. Hence it seems that haptoglobin:haemoglobin complexes can be transferred across cells into bile as is the case in rats. ${ }^{24}$ The significant correlation between the concentration of $\operatorname{sIgA}$ and haptoglobin:haemoglobin complexes in matched serum and bile specimens suggests that in humans, as in rats,${ }^{25}$ the two proteins are transferred in the same system. The concentration of $\beta_{2}$-glycoprotein I in bile relative to its concentration in plasma was much greater than would be expected from its molecular weight. This protein is known to have marked membrane binding properties ${ }^{33}$ and may be involved in lipoprotein metabolism ${ }^{34}$ it is, therefore likely that the relatively high concentration of $\beta_{2}$-glycoprotein I in bile reflects some form of active transfer. Caeruloplasmin may behave similarly, although the concentration in bile was only twice that expected from the molecular weight and the correlation with $\operatorname{IgA}$ was not statistically significant. Clearly it is theoretically possible that, as the 
majority of plasma proteins are made in the liver ${ }^{35}$ there is direct release of proteins into bile. Studies on the labelling kinetics of proteins of rat bile show uniform labelling of serum related proteins, ${ }^{36}$ however, and it would appear that even secretory component, which is released only into bile, is directed first to the sinusoidal face of the cell and then returns across the cell in endocytic vesicles. ${ }^{37}$ Accordingly it is unlikely that there is any direct secretion of proteins into bile.

The amount of IgM in bile is much greater than would be expected from its molecular weight, but in this case there was considerable correlation between the concentration of IgM and the degree of 'sieving' assessed as the difference between the relative concentrations of albumin and $\alpha_{2}$-macroglobulin. The high concentration of IgM in human bile is most probably because of its transfer across cells with secretory component as receptor. This theory is supported by the close correlation between the absolute levels of secretory $\operatorname{IgA}$ and IgM in the bile, is consistent with the small amounts of secretory IgM reported in some human biles ${ }^{38}$ and with earlier work which has shown that rats may transport IgM from plasma to bile using secretory component acting as receptor. ${ }^{39}$ Accordingly it would seem likely that a considerable part of the biliary IgM may have been carried along the same pathways as polymeric IgA.

Thus ultrafiltration across the junctional complexes supplies by far the largest proportion of human bile proteins while specific transport of particular proteins across cells, the major route of entry of proteins into bile in rats, ${ }^{2-4}$ is a less important contributor in the entry of proteins. Furthermore, it would appear that, at least in liver disease, there can be leakage of plasma into bile, presumably, as large amounts of haemoglobin are not present, this is either because of leakage from lymph into bile ductules or of damage to hepatocytes resulting in leakage into bile canaliculi from the space of Disse. Finally it must not be forgotten that quantiatively minor, although possibly functionally important proteins, such as the bile specific glycoproteins described by Svenberg, ${ }^{40}$ appear in bile, although not in serum, and may well, like many biliary enzymes ${ }^{2}$ derive from solubilisation of the proteins from the bile canalicular surface of hepatocytes.

We thank Professor $\mathbf{J}$ W Bridges for providing facilities for us in his laboratories, Dr M Chapple, Dr P Kumar, Mr T Cooke, Dr J T Thornton and Dr M Calladine for provision of bile specimens and Mr B Shipton for transporting specimens and put- ting some of us in contact with each other. Financial support was provided by the Medical Research Council.

\section{References}

1 Lemaître-Coelho I, Jackson GDF, Vaerman J-P. Rat bile as a convenient source of secretory $\operatorname{IgA}$ and free secretory component. Eur J Immunol 1977; 7: 588-90.

2 Mullock BM, Dobrota M, Hinton RH. Sources of the proteins of rat bile. Biochim Biophys Acta 1978; 543: 497-507.

3 Mullock BM, Hinton RH. Transport of proteins from blood to bile. Trends Biochem Sci 1981; 6: 188-91.

4 Orlans E, Peppard J, Fitzharris B et al. Comparative aspects of the transport of proteins from blood to bile. Ann NY Acad Sci 1983; 409: 411-22.

5 Layden TJ, Elias E, Boyer JC. Bile formation in the rat. The role of the paracellular pathway. J Clin Invest 1978; 62: 1375-85.

6 Dive Ch, Nadalini RA, Vaerman J-P, Heremans JF. Origin and nature of the proteins of bile. II: a comparative analysis of serum, hepatic lymph and bile proteins in the dog. Europ J Clin Invest 1974; 4: 241-6.

7 Hall JG, Gyure LA, Payne AWR. Comparative aspects of the transport of immunoglobulin $A$ from blood to bile. Immunology 1980; 41: 899-902.

8 John WG, Mullock BM, Hinton RH. Proteins of guinea pig bile:- selective resorption in the gall bladder. Biosci Rep 1983; 3: 389-94.

9 Dive $\mathrm{Ch}$, Heremans JF. Nature and origin of the proteins of bile. I: a comparative analysis of serum and bile proteins in man. Europ J Clin Invest 1974; 4: 235-9.

10 Nagura H, Smith PP, Nakane PK, Brown WR. IgA in human bile and liver. $J$ Immunol 1981; 126: 587-95.

11 Delacroix DC, Dive C, Rambaud JC, Vaerman JP. IgA subclasses in various secretions and in serum. Immunology 1982; 47: 383-5.

12 Phillips JO, Kutteh WH, Mestecky J. Properties of IgA in human hepatic bile. Fed Proc 1981; 40: 607.

13 Thompson RA, Carter R, Stokes PP, Geddes AM, Goodall JAD. Serum immunoglobulins: complement component levels and auto-antibodies in liver disease. Clin Exp Immunol 1973; 14: 335-46.

14 Fitzharris B. The measurement by radioimmunoassay of secretory component in normal and pathological human sera and body fluids. MD Thesis, University of Otago, Dunedin, New Zealand, 1981.

15 Pelletier G, Briantais MJ, Buffet C, Pillot J, Etienne JP. Serum and intestinal secretory IgA in alcoholic cirrhosis of the liver. Gut 1981; 23: 475-85.

16 Iscaki S, Buffet C, Briantais MJ, Geneste C, Etienne J-P, Pillot J. IgA secretoires seriques dans les maladies hepatiques et dans diverses situations physiologique ou pathologique humaines. Gastroenterol Clin Biol 1981; 5: 305-13.

17 Ollivier JP, Muzellec JJ, Delamourd L et al. Rapport $\operatorname{IgA} /$ transferrine et hepatopathies alcooliques. Med Armees 1981; 9: 303-6. 
18 Delacroix DL, Reynaert M, Pauwels S, Geubel AP, Vaerman JP. High serum levels of secretory $\operatorname{IgA}$ in liver disease. Possible liver origin of the circulating secretory component. Dig Dis Sci 1982; 27: 333-40.

19 Farris MA, Chandy KG, Ashdown K, Elias E, Burnett D. Serum secretory component: a potential marker of biliary obstruction. Clin Chim Acta 1984; 133: 65-73.

20 Hsu SM, Hsu PL. Demonstration of $\operatorname{IgA}$ and secretory component in human hepatocytes. Gut 1980; 21: 985-9.

21 Delacroix DL, Furtado-Barreira G, de Hemptinne B, Goudswaard, J, Dive C, Vaerman JP. The liver in the IgA secretory immune systems. Dogs but not rats and rabbits are suitable models for human studies. Hepatology 1983; 3: 980-8.

22 Dooley JS, Potter BJ, Thomas HC, Sherlock S. A comparative study of the biliary secretion of human dimeric and monomeric immunoglobulin $\mathrm{A}$ in the rat and in man. Hepatology 1982; 2: 323-7.

23 Foss-Bowman C, Jones AL, Dejbaksh S, Goldman IS. Immunofluorescent and immunocytochemical localisation of secretory component and immunoglobulins in human liver. Ann NY Acad Sci 1983; 409: 822-3.

24 Hinton RH, Dobrota M, Mullock BM. Haptoglobin mediated transfer of haemoglobin from serum into bile. FEBS Letters 1980; 112: 247-50.

25 Hinton RH, Benford D, Shaw LJ, Mullock BM. Receptor mediated transfer of proteins from blood to bile. In: Reid E, Cook GMW, Moore DJ, eds. Methodological developments in biochemistry vol. 10. London: Plenum Press, 1984: 211-24.

26 Delacrooix DL, Hodgson HJF, McPherson A, Dive C, Vaerman J-P. Selective transport of polymeric immunoglobulin A in bile. Quantitative relationships of monomeric and polymeric immunoglobulin $A$, immunoglobulin $M$ and other proteins in serum, bile and saliva. J Clin Invest 1982; 70: 230-41.

27 Mullock BM, Issa FS, Hinton RH. Bile 5'nucleotidase in the serum of jaundiced rats. Clin Chim Acta 1977; 79: 129-40.

28 Axelsen NH, Knoll J, Weeke B. A manual of quantitative immunoelectrophoresis. Oslo: Universitets- forlaget, 1973.

29 Peppard J. Quantitative estimation of IgA in rats, a comparison of two methods. J Immunol Methods 1979; 31: 129-39.

30 Socken DJ, Underdown BJ. Comparison of human, bovine and rabbit secretory component - immunoglobulin interactions. Immunochemistry 1978; 15: 499-506.

31 Ham AW, Cormack DH. Histology 8th edition. Philadelphia: JB Lipincott, 1979.

32 Balant L, Fabre J. Clinical Relevance of different electrophoretic methods for the analysis of urinary proteins. In: Dubach UC, Schmidt U, eds. Bern: Hans Huber, 1979: 216-34.

33 Schousbx I. Characterisation of the interaction between $\beta_{2}$-glycoprotein 1 and mitochondria, platelets, liposomes and bile acids. Int J Biochem 1983; 15: $1393-401$.

34 Wurm H, Beubler E, Polz E, Holasek A, Kostner GM. (1982): Studies on the possible function of $\beta_{2}$ glycoprotein 1: influence in triglyceride metabolism in the rat. Metabolism 1982; 31: 484-6.

35 Miller LL, John DW. In: Rothschild MA, Waldmann T, eds. Plasma protein metabolism. New York: Academic Press, 1970: 207-22.

36 Mullock BM, Hinton RH. Mechanisms by which newly made glycoproteins are transferred from hepatocytes into bile. FEBS Letters 1979; 106: 121-4.

37 Mullock BM, Hinton RH, Dobrota M, Peppard J, Orlans E. Distribution of secretory component in hepatocytes and its mode of transfer into bile. Biochem J 1980; 190: 819-26.

38 Delacroix DL, Jonard P, Dive C, Vaerman JP. Serum IgM-bound secretory component (sIgM) in liver diseases. Comparative molecular state of the secretory component in serum and bile. J Immunol 1982; 129: 133-8.

39 Peppard JV, Jackson E, Hall JG. The occurrence of secretory IgM in the bile of rats. Clin Exp Immunol 1983; 53: 623-6.

40 Svenberg C. Carcinoembryonic antigen-like substances of human bile. Isolation and partial purification. Int J Cancer 1976; 17: 588-96. 